\title{
PERCEPTION STUDENT OF DEPARTMENT GUIDANCE AND COUNSELING AT UNIVERSITAS MUHAMMADIYAH METRO INTO SCHOOL COUNSELOR PROFESSION
}

SERLI NOVITA SARI \& NURUL ATIEKA

Program Studi Bimbingan dan Konseling UM Metro

\begin{abstract}
Guidance and Counseling Teaching profession is a profession with dignity and requiring scientific competence and qualifications. Many emerging negative perception, even from students of guidance and counseling to the profession of guidance and counseling. The problem in this research is formulated as follows: "What are the perceptions students of Guidance and Counselling, University of Muhammadiyah Metro the teaching profession Counseling?". The goal is to find out how students' perceptions of Guidance and Counselling, University of Muhammadiyah Metro the teaching profession Guidance and Counseling. The method used is quantitative descriptive. The population is students of guidance and counseling, the sample totaled 175 students. Instruments used in the form of Likert scale. The data analysis technique used percentages. The results showed that students' perceptions BK UM Metro is at a very high category to the teaching profession Guidance and Counseling. Suggestions put forward are: Based on these results, the researchers gave some suggestions are as follows: 1) for lecturers to add hours of practicum BK for students, and provide student guidance and counseling opportunities to interact more with teacher guidance and counseling directly in schools, and 2) the students are expected to apply to run a positive perception of the teaching profession Counseling well.
\end{abstract}

Keyword: Perception, Student, Guidance and Counseling

\section{PENDAHULUAN}

Guru

Bimbingan

dan

Konseling pada dasarnya merupakan profesi yang sangat mulia dengan tujuan utamanya memberikan bantuan kepada peserta didik. Bantuan yang dimaksud yaitu berkaitan dengan pengembangan pribadi, sosial, belajar, karier, kehidupan keagamaan dan kewarganegaraan, sesuai potensi yang peserta didik miliki secara optimal. Guru Bimbingan dan Konseling sebagai sebuah profesi yang mulia memiliki tugas dan tanggung jawab keprofesian yang bertujuan untuk membantu peserta didik dalam upaya mencapai tugas perkembangan yang optimal. Permendikbud No 81A Tahun 2013 tentang Implementasi kurikulum 2013 menjelaskan bahwa 
"Guru Bimbingan dan Konseling atau konselor adalah guru yang mempunyai tugas, tanggung jawab, wewenang, dan hak secara penuh dalam kegiatan pelayanan bimbingan dan konseling terhadap sejumlah siswa." Selain itu menurut Harnoto \& Sudarmaji (2012) "Guru Bimbingan dan Konseling adalah orang yang memiliki keahlian dalam bidang pelayanan konseling, sebagai tenaga professional.

Tugas keprofesian guru Bimbingan dan Konseling sesuai dengan peraturan menteri dan juga pendapat ahli menggambarkan betapa profesi guru Bimbingan dan Konseling sangat dibutuhkan dan merupakan profesi yang memerlukan kompetensi dan kualifikasi keprofesian yang diakui dan melekat dalam penyandang profesi tersebut.

Upaya

penegakan

profesionalitas profesi guru

Bimbingan dan Konseling menjadi tanggung jawab banyak pihak. Selain guru Bimbingan dan Konseling, mahasiswa calon guru Bimbingan dan Konseling juga memegang peran yang sangat besar dalam menjaga dan menumbuhkan keprofesionalitas profesi guru Bimbingan dan Konseling.Salah satu hal yang dapat dilakukan oleh mahasiswa program studi bimbingan dan konseling adalah memahami secara utuh tentang hakikat guru Bimbingan dan Konseling, TUPOKSI, peran, serta tanggung jawab keprofesian guru Bimbingan dan Konseling.

Namun saat ini persepsi negatif terhadap profesi guru Bimbingan dan Konseling sering muncul dari berbagai pihak, tidak terkecuali juga muncul dari calon guru Bimbingan dan Konseling itu sendiri, yaitu mahasiswa program studi Bimbingan dan Konseling. Mahasiswa Bimbingan dan Konseling seharusnya memiliki persepsi yang positif terhadap profesi yang akan disandang dan dijalaninya setelah masa pendidikan berakhir.

Persepsi negatif yang muncul bahkan dari calon mengemban profesi guru Bimbingan dan Konseling itu sendiri merupakan wujud pengalaman masa lalu yang kurang mengenakan dari mahasiswa dengan guru Bimbingan dan Konseling selama berada di SMP ataupun SMA. Muncullan persepsi negatif terhadap guru Bimbingan dan Konseling mengindikaskan bahwa mahasiswa pernah mengalami suatu masalah, bahkan mengalami pengalaman yang 
tidak "mengenakan" dengan guru Bimbingan dan Konseling. Menurut (Drever dalam Sasanti: 2008), Persepsi adalah suatu proses pengenalan atau identifikasi sesuatu dengan menggunakan panca indera, kesan yang diterima individu sangat tergantung pada seluruh pengalaman yang telah diperoleh melalui proses berpikir dan belajar, serta dipengaruhi oleh faktor yang berasal dari dalam diri individu.

Kemudian menurut Rakhmat (2011) terbentuknya persepsi pada diri individu dipengaruhi oleh banyak hal yaitu: a) faktor fungsional, yang berasal dari kebutuhan, pengalaman masa lalu, sifat-sifat individual dan hal-hal lain yang termasuk apa yang kita sebut sebagai faktor-faktor personal. Yang menentukan persepsi bukan jenis atau bentuk stimuli, tetapi karakteristik orang yang memberikan stimuli itu. Bartley (dalam Nirwana, 1998) Persepsi merupakan suatu kegiatan atau proses untuk mengetahui objek, fakta berdasarkan pengalaman pribadinya atau pikirannya. Dalil ini berarti bahwa objek-objek yang mendapat tekanan dalam persepsi kita biasanya objek-objek yang memenuhi tujuan individu yang melakukan persepsi.

Adanya persepsi negatif kepada profesi guru Bimbingan dan Konseling juga terjadi oleh calon mahasiswa Program Studi Bimbingan dan Konseling UM Metro. Berdasarkan pra survei yang peneliti lakukan pada mahasiswa Bimbingan dan Konseling Universitas Muhammadiyah Metro semester genap pada tanggal 14 April - 19 April 2014, melalui wawancara terhadap mahasiswa Bimbingan dan Konseling Universitas Muhammadiyah Metro semester 2, 4 dan 6 sebanyak 10 mahasiswa diantaranya diperoleh data sebagai berikut:

1. Mahasiswa berpandangan bahwa guru Bimbingan dan Konseling tidak disukai peserta didik.

2. Mahasiswa menganggap bahwa profesi guru Bimbingan dan Konseling memiliki tugas yang berat karena menangani semua peserta didik, baik yang bermasalah maupun yang tidak bermasalah.

Persepsi negatif mahasiswa Bimbingan dan Konseling secara umum terhadap profesi guru 
Bimbingan dan Konseling menganggap guru Bimbingan dan Konseling sebagai polisi sekolah yang tidak disukai peserta didik. Selain itu guru Bimbingan dan Konseling dianggap sebagai profesi yang sangat berat, karena menangani semua peserta didik. Peserta didik yang bermasalah maupun yang tidak bermasalah perlu perhatian dan pemberian layanan oleh guru Bimbingan dan Konseling.

Seharusnya profesi tersebut sebagai sahabat peserta didik yang membantu dalam mengatasi masalahnya, mengembangkan potensi, bakat dan minatnya secara optimal. Sehingga guru Bimbingan dan Konseling dapat disukai peserta didik. Profesi guru Bimbingan dan Konseling memang menangani semua peserta didik. Namun ketika menjalankan profesi dengan senang hati tanpa paksaan akan terasa lebih ringan. Keberhasilan peserta didik dapat menimbulkan perasaan senang dan puas dalam hati guru Bimbingan dan Konseling yang telah membimbing dan membantu peserta didik.

Terdapat beberapa faktor yang dimungkinkan mempengaruhi munculnya persepsi negatif pada diri mahasiswa Bimbingan dan Konseling, yaitu diantaranya kurangnya pengetahuan dasar mahasiswa Bimbingan dan Konseling mengenai profesi guru Bimbingan dan Konseling yang sesungguhnya. Mahasiswa Bimbingan dan Konseling hanya bertumpu pada apa yang mereka lihat dan alami selama berinteraksi dengan guru Bimbingan dan Konseling di SLTP atau SLTA, tanpa mengkaji ulang melalui buku dan bahan bacaan lainnya. Kondisi ini diperburuk dengan aktivitas guru Bimbingan dan Konseling selama ini yang mengedepankan hukuman terhadap peserta didik yang melakukan kesalahan tanpa melihat kondisi yang melatarbelakangi kesalahan peserta didik.

Demikian pula terdapat mahasiswa Bimbingan dan Konseling saat menentukan pilihan jurusan pendidikan Bimbingan dan Konseling bukan atas dasar kemauan dirinya sendiri, namun hanya sebatas memenuhi keinginan orang tuanya. Ada pula mahasiswa Bimbingan dan Konseling memilih jurusan Bimbingan dan Konseling karena terpengaruh oleh teman. Hal ini berdampak pada 
saat perkuliahan berlangsung, mahasiswa Bimbingan dan Konseling yang mengambil jurusan bukan atas kemauan sendiri dalam mengikuti perkuliahan cenderung tidak serius, tidak aktif saat diberikan materi dikelas, malas mengerjakan tugas yang diberikan dosen. Mahasiswa yang mengikuti proses perkuliahan seperti itu mengakibatkan mahasiswa kurang menguasai teori dan praktik disiplin keilmuan Bimbingan dan Konseling. Padahal untuk dapat menjalankan profesi guru Bimbingan dan Konseling seharusnya atas dasar panggilan nurani untuk mengabdi kepada masyarakat dan negara serta yang paling penting bukan atas paksaan dari siapapun. Hal-hal yang semacam ini kurang dapat memunculkan kecintaan terhadap profesi yang akan dijalaninya, justru menjadikan beban sehingga muncullah persepsi negatif. Jika persepsi-persepsi seperti hasil pra survei dibiarkan akan membuat kurang baiknya pencitraan profesi Bimbingan dan Konseling kedepannya.

Mahasiswa Bimbingan dan Konseling perlu membangun wawasan serta keterampilan dalam pelayanan bimbingan dan konseling sehingga ketika menjadi guru Bimbingan dan Konseling dapat melaksanakan tugasnya menurut aturan keilmuannya, tidak melanggar kode etik profesinya dan memperhatikan nilai-nilai kemanusiaan. Guru Bimbingan dan Konseling dalam melaksanakan pelayanan bimbingan dan konseling akan menimbulkan persepsi untuk profesinya secara umum.

Berangkat dari masalah yang ditemukan, maka perlu dilakukan penelitian dan kajian yang mendalam tentang persepsi mahasiswa program studi Bimbingan dan Konseling terhadap profesi guru Bimbingan dan Konseling. Masalah dalam penelitian ini dirumuskan sebagai berikut: "Bagaimana persepsi mahasiswa program studi Bimbingan dan Konseling Universitas Muhammadiyah Metro terhadap profesi guru Bimbingan dan Konseling?". Tujuan yang hendak dicapai adalah untuk mengetahui bagaimana persepsi mahasiswa Bimbingan dan Konseling Universitas Muhammadiyah Metro terhadap profesi guru Bimbingan dan Konseling.

\section{METODE PENELITIAN}


Penelitian ini menggunakan metode penelitian kuantitatif deskriptif. Metode penelitian kuantitatif deskriptif merupakan pendekatan penelitian kuantitatif yang paling dasar, dalam arti tidak memberikan perlakuan, manipulasi atau pengubahan pada variabelvariabel bebas, tetapi menggambarkan suatu kondisi apa adanya. Menurut Sukmadinata (2012) menyatakan bahwa:

Penelitian deskriptif adalah suatu bentuk penelitian yang paling dasar, karena peneliti tidak melakukan manipulasi atau memberikan perlakuanperlakuan tertentu terhadap variabel atau merancang sesuatu yang diharapkan terjadi pada variabel, tetapi semua kegiatan, keadaan, kejadian, aspek, komponen atau variabel berjalan sebagaimana adanya.

Populasi dalam penelitian ini meliputi seluruh mahasiswa Bimbingan dan Konseling Universitas Muhammadiyah Metro semester ganjil, dengan perincian sebagai berikut:

Tabel 1. Sebaran Populasi

\begin{tabular}{|c|c|c|}
\hline No & Semester & Jumlah \\
\hline 1 & Semester 7 & 77 \\
\hline 2 & Semester 5 & 53 \\
\hline 3 & Semester 3 & 83 \\
\hline 4 & Semester 1 & 97 \\
\hline & Jumlah & $\mathbf{3 1 0}$ \\
\hline
\end{tabular}

Sumber data: BAAK Universitas Muhammadiyah Metro

Jumlah sampel yang dibutuhkan adalah 175 mahasiswa Bimbingan dan Konseling dan ditentukan dengan teknik teknik Proportionate Sratifeid Random Sampling. Sejumlah 175 mahasiswa tersebut diambil dengan cara menggunakan sistem undian. Metode yang peneliti gunakan untuk menentukan jumlah sampel adalah menggunakan rumus Slovin dalam Ridwan (2005), sebagai berikut:

$n=N /\left(1+N e^{2}\right)$

Keterangan:

n : Jumlah sampel

$\mathrm{N}$ : Jumlah populasi

e : Batas toleransi kesalahan

(error tolerance)

Sebaran sampel dalam penelitian ini dapat dilihat pada tabel di bawah ini:

Tabel 2. Distribusi Sampel Penelitian

\begin{tabular}{|l|c|}
\hline \multicolumn{1}{|c|}{ Semester } & Jumlah \\
\hline Semester 7 & 43 \\
\hline Semester 5 & 30 \\
\hline Semester 3 & 47 \\
\hline Semester 1 & 55 \\
\hline \multicolumn{2}{|c|}{ Jumlah } \\
\hline
\end{tabular}


Instrumen pengumpulan data menggunakan skala likert, dan data penelitian dianalisis secara deskriptif kuantitatif dengan menggunakan rumus:

$$
P=n: N \times 100 \%
$$

Keterangan :

$$
\begin{array}{ll}
\mathrm{P} & =\text { Persentase } \\
\mathrm{n} & =\text { Skor nyata } \\
\mathrm{N} & =\text { Skor Ideal }
\end{array}
$$

\section{HASIL}

Hasil penelitian secara rinci akan disajikan berikut ini:

\section{a) Tingkat Persepsi Mahasiswa Bimbingan dan Konseling Semester 7 terhadap Profesi Guru Bimbingan dan Konseling}

Tingkat persepsi mahasiswa Bimbingan dan Konseling semester 7 terhadap profesi guru Bimbingan dan Konseling, maka data penelitian yang telah dianalisis dibandingkan dengan

\begin{tabular}{|c|c|c|c|c|}
\hline 4 & $37-53$ & Kurang & 0 & $0 \%$ \\
\hline 5 & $20-36$ & $\begin{array}{l}\text { Sangat } \\
\text { kurang }\end{array}$ & 0 & $0 \%$ \\
\hline \multicolumn{3}{|c|}{ Jumlah } & 43 & $100 \%$ \\
\hline
\end{tabular}
kategori yang telah ditentukan sebagai berikut:

\begin{tabular}{|c|c|c|c|c|} 
Tabel & $\begin{array}{l}\text { 3.Tingkat } \\
\text { Bimbingan } \\
\text { Semester 7 }\end{array}$ & $\begin{array}{c}\text { Persepsi } \\
\text { dan } \\
\text { terhadap Profesi Guru }\end{array}$ & $\begin{array}{c}\text { Mahasiswa } \\
\text { Konseling } \\
\text { Bimbingan dan Konseling }\end{array}$ \\
\hline \begin{tabular}{c|c|c|c|c|} 
N \\
o
\end{tabular} & Rentangan & Kategori & $\mathrm{F}$ & $\%$ \\
\hline 1 & $88-100$ & $\begin{array}{c}\text { Sangat } \\
\text { tinggi }\end{array}$ & 32 & $74,41 \%$ \\
\hline 2 & $71-87$ & Tinggi & 11 & $25,59 \%$ \\
\hline 3 & $54-70$ & Cukup & 0 & $0 \%$ \\
\hline
\end{tabular}

Pencapaian skor pada setiap kategori akan disajikan dalam bentuk diagram berikut:

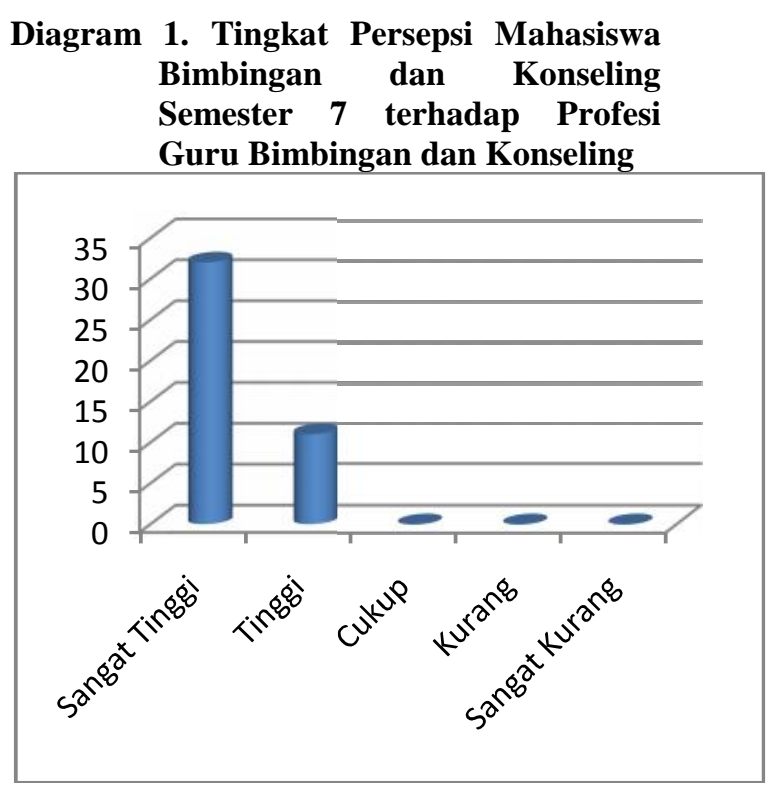

Berdasarkan diagram di atas terlihat bahwa frekuensi terbesar adalah berada pada kategori sangat tinggi, yaitu sebesar 32 dengan besaran persentase $74,41 \%$. Selain itu perolehan nilai rata-rata berada pada kategori sangat tinggi. Sehingga dapat diambil kesimpulan bahwa persepsi mahasiswa Bimbingan dan Konseling semester 7 terhadap guru Bimbingan dan Koseling berada pada kategori sangat tinggi.
b) Tingkat Persepsi Mahasiswa Bimbingan dan Konseling 
Semester 5 terhadap Profesi Guru Bimbingan dan Konseling

Tingkat persepsi mahasiswa Bimbingan dan Konseling semester 5terhadap profesi guru Bimbingan dan Konseling, maka data penelitian yang telah dianalisis dibandingkan dengan kategori yang telah ditentukan sebagai berikut:

Tabel 4. Tingkat Persepsi Mahasiswa Bimbingan dan Konseling Semester 5 terhadap Profesi Guru Bimbingan dan Konseling

\begin{tabular}{|c|c|c|c|c|}
\hline No & $\begin{array}{c}\text { Rentangan } \\
\text { Skor }\end{array}$ & Kategori & $\mathrm{F}$ & $\%$ \\
\hline 1 & $88-100$ & $\begin{array}{c}\text { Sangat } \\
\text { tinggi }\end{array}$ & 14 & $46,67 \%$ \\
\hline 2 & $71-87$ & Tinggi & 16 & $53,33 \%$ \\
\hline 3 & $54-70$ & Cukup & 0 & $0 \%$ \\
\hline 4 & $37-53$ & Kurang & 0 & $0 \%$ \\
\hline 5 & $20-36$ & $\begin{array}{c}\text { Sangat } \\
\text { kurang }\end{array}$ & 0 & $0 \%$ \\
\hline & Jumlah & 30 & $100 \%$ \\
\hline
\end{tabular}

Untuk Tingkat persepsi mahasiswa Bimbingan dan Konseling semseter 5 disajikan dalam bentuk diagram berikut:

Diagram 2. Tingkat Persepsi Mahasiswa Bimbingan dan Konseling Semester 5

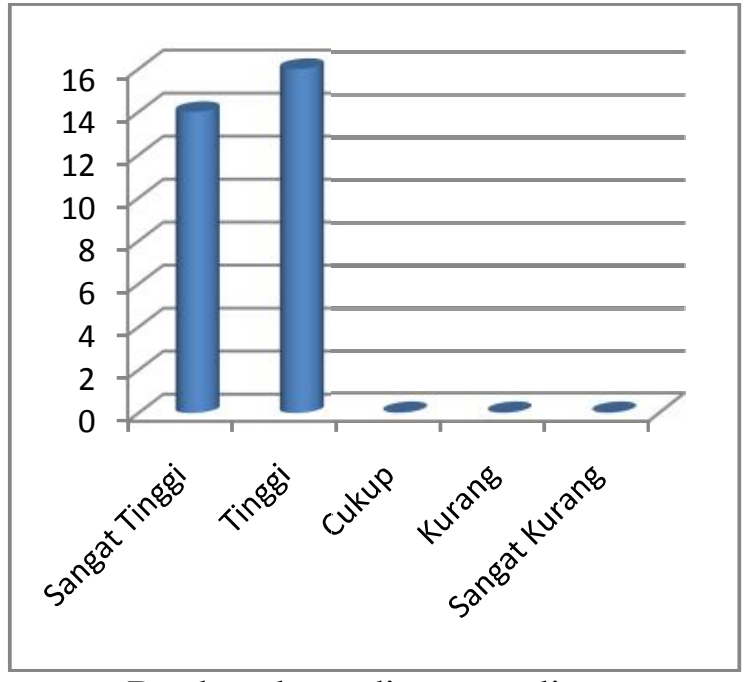

Berdasarkan diagram di atas

terlihat bahwa frekuensi terbesar adalah berada pada kategori tinggi, yaitu sebesar 16 dengan besaran persentase $53,33 \%$. Selain itu perolehan nilai rata-rata berada pada kategori tinggi. Sehingga dapat diambil kesimpulan bahwa persepsi mahasiswa Bimbingan dan Konseling semester 5 terhadap guru Bimbingan dan Koseling berada pada kategori tinggi.

c) Tingkat Persepsi Mahasiswa Bimbingan dan Konseling Semester 3 terhadap Profesi Guru Bimbingan dan Konseling

Tingkat persepsi mahasiswa Bimbingan dan Konseling semester 3terhadap profesi guru Bimbingan dan Konseling, maka data penelitian yang telah dianalisis dibandingkan dengan 
kategori yang telah ditentukan sebagai berikut:

Tabel 5. Tingkat Persepsi Mahasiswa Bimbingan dan Konseling Semester 3 terhadap Profesi Guru Bimbingan dan Konseling

\begin{tabular}{|c|c|c|c|c|}
\hline No & $\begin{array}{c}\text { Rentangan } \\
\text { Skor }\end{array}$ & Kategori & $\mathrm{F}$ & $\%$ \\
\hline 1 & $88-100$ & $\begin{array}{c}\text { Sangat } \\
\text { tinggi }\end{array}$ & 27 & $57,45 \%$ \\
\hline 2 & $71-87$ & Tinggi & 20 & $42,55 \%$ \\
\hline 3 & $54-70$ & Cukup & 0 & $0 \%$ \\
\hline 4 & $37-53$ & Kurang & 0 & $0 \%$ \\
\hline 5 & $20-36$ & $\begin{array}{c}\text { Sangat } \\
\text { kurang }\end{array}$ & 0 & $0 \%$ \\
\hline \multicolumn{7}{|c|}{ Jumlah } & 47 & $100 \%$ \\
\hline
\end{tabular}

Tingkat persepsi mahasiswa Bimbingan dan Konseling semester 3 terhadap guru Bimbingan dan Konseling disajikan dalam bentuk diagram berikut:

Diagram 3. Tingkat Persepsi Mahasiswa Bimbingan dan Konseling Semester 3

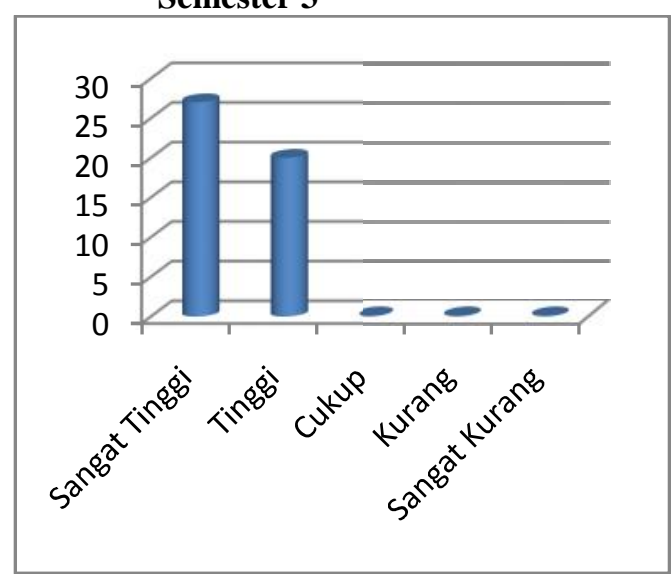

Berdasarkan diagram di atas

terlihat bahwa frekuensi terbesar adalah berada pada kategori sangat tinggi, yaitu sebesar 27 dengan besaran persentase $57,45 \%$. Selain itu perolehan nilai rata-rata berada pada kategori sangat tinggi. Sehingga dapat diambil kesimpulan bahwa persepsi mahasiswa Bimbingan dan Konseling semester 3 terhadap guru Bimbingan dan Koseling berada pada kategori sangat tinggi.

d) Tingkat Persepsi Mahasiswa Bimbingan dan Konseling Semester 1 terhadap Profesi Guru Bimbingan dan Konseling

Tingkat persepsi mahasiswa Bimbingan dan Konseling semester 1terhadap profesi guru Bimbingan dan Konseling, maka data penelitian yang telah dianalisis dibandingkan dengan kategori yang telah ditentukan sebagai berikut:

Tabel 6. Tingkat Persepsi Mahasiswa Bimbingan dan Konseling Semester 1 terhadap Profesi Guru Bimbingan dan Konseling

\begin{tabular}{|c|c|c|c|c|}
\hline No & $\begin{array}{c}\text { Rentangan } \\
\text { Skor }\end{array}$ & Kategori & $\mathrm{F}$ & $\%$ \\
\hline 1 & $88-100$ & $\begin{array}{l}\text { Sangat } \\
\text { tinggi }\end{array}$ & 30 & $54,55 \%$ \\
\hline 2 & $71-87$ & Tinggi & 25 & $45,45 \%$ \\
\hline 3 & $54-70$ & Cukup & 0 & $0 \%$ \\
\hline 4 & $37-53$ & Kurang & 0 & $0 \%$ \\
\hline 5 & $20-36$ & $\begin{array}{l}\text { Sangat } \\
\text { kurang }\end{array}$ & 0 & $0 \%$ \\
\hline \multicolumn{3}{|c|}{ Jumlah } & 55 & $100 \%$ \\
\hline
\end{tabular}

Tingkat persepsi mahasiswa Bimbingan dan Konseling semester 1 terhadap guru Bimbingan dan Konseling, maka frekuensi pencapaian skor pada setiap kategori akan 
disajikan dalam bentuk diagram berikut:

Diagram 4. Tingkat Persepsi Mahasiswa Bimbingan dan Konseling Semester 1

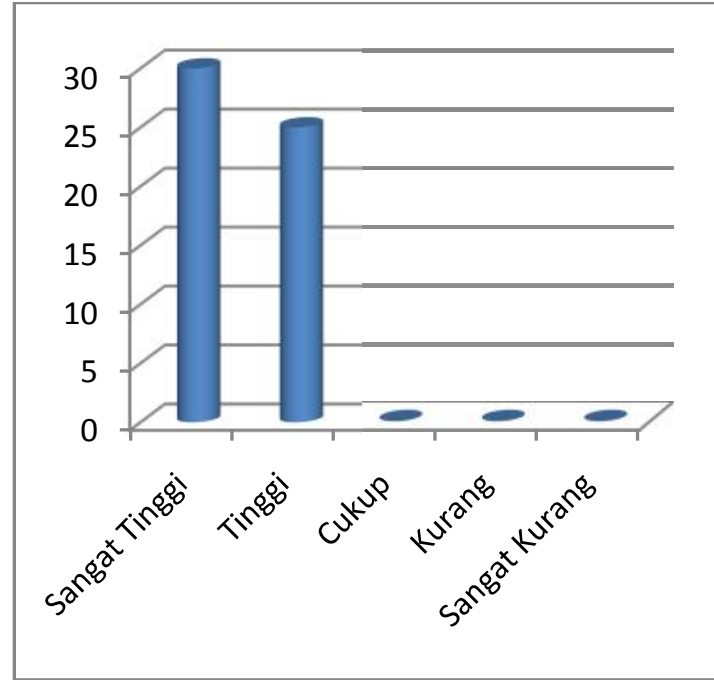

Berdasarkan diagram di atas terlihat bahwa frekuensi terbesar adalah berada pada kategori sangat tinggi, yaitu sebesar 30 dengan besaran persentase $54,55 \%$. Selain itu perolehan nilai rata-rata berada pada kategori sangat tinggi. Sehingga dapat diambil kesimpulan bahwa persepsi mahasiswa Bimbingan dan Konseling semester 1 terhadap guru Bimbingan dan Koseling berada pada kategori sangat tinggi.

\section{e) Tingkat Persepsi Mahasiswa Bimbingan dan Konseling Universitas Muhammadiyah Metro tehadap Profesi Guru Bimbingan dan Konseling}

Tingkat persepsi mahasiswa Bimbingan dan Konseling secara keseluruhan terhadap profesi guru Bimbingan dan Konseling, maka data penelitian yang telah dianalisis dibandingkan dengan kategori yang telah ditentukan sebagai berikut:

Tabel 7. Pengkategorian Pencapaian Skor Persepsi Mahasiswa Bimbingan dan Konseling terhadap Profesi Guru Bimbingan dan Konseling

\begin{tabular}{|c|c|c|c|c|}
\hline No & $\begin{array}{c}\text { Rentangan } \\
\text { Skor }\end{array}$ & Kategori & $\mathrm{F}$ & $\%$ \\
\hline 1 & $88-100$ & $\begin{array}{l}\text { Sangat } \\
\text { tinggi }\end{array}$ & 103 & $58,85 \%$ \\
\hline 2 & $71-87$ & Tinggi & 72 & $41,15 \%$ \\
\hline 3 & 54-70 & Cukup & 0 & $0 \%$ \\
\hline 4 & $37-53$ & Kurang & 0 & $0 \%$ \\
\hline 5 & $20-36$ & $\begin{array}{l}\text { Sangat } \\
\text { kurang }\end{array}$ & 0 & $0 \%$ \\
\hline \multicolumn{3}{|c|}{ Jumlah } & 175 & $100 \%$ \\
\hline
\end{tabular}

Untuk menentukan kategori pencapaian skor persepsi mahasiswa Bimbingan dan Konseling terhadap guru Bimbingan dan Konseling, maka frekuensi pencapaian skor pada setiap kategori akan disajikan dalam bentuk diagram berikut:

Diagram 5. Frekuensi Pencapaian Skor SkalaTingkat Persepsi Mahasiswa Bimbingan dan KonselingUniversitas Muhammadiyah Metro

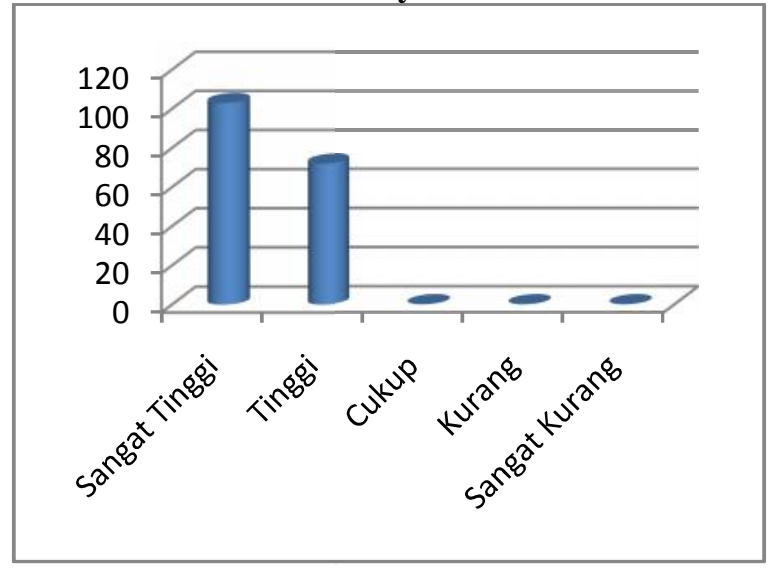


Berdasarkan diagram di atas terlihat bahwa frekuensi terbesar adalah berada pada kategori sangat tinggi, yaitu sebesar 103 dengan besaran persentase $58,85 \%$. Selain itu perolehan nilai rata-rata berada pada kategori sangat tinggi. Sehingga dapat diambil kesimpulan bahwa persepsi mahasiswa Bimbingan dan Konseling Universitas Muhammadiyah Metro terhadap profesi guru Bimbingan dan Konseling berada pada kategori sangat tinggi.

\section{PEMBAHASAN}

Peneliti memberikan skala kepada mahasiswa Bimbingan dan Konseling untuk mengetahui seberapa tinggi tingkat persepsi mahasiswa Bimbingan dan Konseling terhadap profesi guru Bimbingan dan Konseling. Mahasiswa Bimbingan dan Konseling menilai profesi Bimbingan dan Konseling sesuai dengan kompetensi-kompetensi yang harus dikuasai guru Bimbingan dan Konseling. Berdasarkan Permendiknas No 27 Tahun 2008 tentang Standar $\begin{array}{llr}\text { Kualifikasi } & \text { Akademik dan } \\ \text { Kompetensi } & \text { Konselor bahwa }\end{array}$ kompetensi konselor atau guru bimbingan dan konseling meliputi kompetensi pedagogik, kompetensi kepribadian, kompetensi sosial dan kompetensi profesional. tingkat persepsi mahasiswa Bimbingan dan Konseling dapat dilihat dari deskripsi dan analisis data hasil penelitian.

$$
\text { Menurut Nurhadi (2005:6) }
$$

suatu profesi apabila memenuhi lima syarat, yaitu (a) Didasarkan atas sosok ilmu pengetahuan teoretik, (b) Komitmen untuk menerapkan pengetahuan dan keterampilannya dalam praktek secara otonom (c) Adanya kode etik profesi sebagai instrumen untuk memonitor tingkat ketaatan anggotaya dan sistem sanksi yang perlu diterapkan, (d) Adanya organisasi profesi yang mengembangkan, menjaga, dan melindungi profesi, dan (e) Sistem sertifikasi bagi individu yang memiliki pengetahuan dan keterampilan untuk dapat menjalankan profesi tersebut. Demikian pula persepsi mahasiswa Bimbingan dan Konseling terhadap profesi guru Bimbingan dan Konseling, mahasiswa Bimbingan dan Konseling memiliki persepsi bahwa profesi guru Bimbingan dan Konseling didasari pada ilmu 
pengetahuan secara teoritik dengan memiliki teori-teori yang baku, guru Bimbingan dan Konseling juga memiliki otonomi untuk melaksanakan profesinya. Profesi guru Bimbingan dan Konseling memiliki kode etik yang harus dipatuhi oleh seluruh anggota organisasi profesinya dan dapat bekerjasama dengan profesi bidang lainnya.

Sesuai dengan penjelasan di atas persepsi mahasiswa Bimbingan dan Konseling menggambarkan bahwa guru Bimbingan dan Konseling adalah sebagai profesi dan pelaksanaanya sesuai dengan indikator-indikator penelitian yang ada pada skala instrumen penelitian. Secara rinci tingkat persepsi mahasiswa dapat dijelaskan sesuai tingkat semester sebagai berikut. Tingkat persepsi mahasiswa Bimbingan dan Konseling semester 7 tergolong sangat baik dengan hasil persentase skala sebesar 91,91\%. Demikian pula disetiap aspek penilaian yang menjadi indikator tingkat persepsinya. Diantara tingkatan semester lainnya, semester 7 memiliki tingkat persepsi yang paling tinggi dan positif. Tingkat persepsi mahasiswa Bimbingan dan Konseling semester 5 termasuk dalam kategori baik dengan hasil persentase skala sebesar 87,72\%. Demikian pula disetiap aspek penilaian yang menjadi indikator tingkat persepsinya. Tingkat persepsi mahasiswa Bimbingan dan Konseling semester 3 tergolong sangat baik dengan hasil persentase skala sebesar 87,35\%. Demikian pula disetiap aspek penilaian yang menjadi indikator tingkat persepsinya. Tingkat persepsi mahasiswa Bimbingan dan Konseling semester 1 tergolong baik saja dengan hasil persentase skala sebesar 86,58\%. Demikian pula disetiap aspek penilaian yang menjadi indikator tingkat persepsinya. Meskipun demikian semester 1 memiliki tingkat persepsi terendah.

Berdasarkan penjabaran di atas, maka dapat disimpulkan bahwa guru bimbingan dan konseling menurut persepsi mahasiswa Bimbingan dan Konseling memiliki empat kompetensi dasar dan memenuhi persyaratan profesi guru Bimbingan dan Konseling yang ada dapat menyelenggarakan layanan Bimbingan dan Konseling secara profesional. 
KESIMPULAN DAN SARAN

\section{Kesimpulan}

Kesimpulan dari penelitian adalah:

1. Tingkat persepsi mahasiswa Bimbingan dan Konseling semester 7 tergolong sangat baik dengan hasil persentase skala sebesar 91,91\%. Tingkat persepsi mahasiswa Bimbingan dan Konseling semester 5 termasuk dalam kategori baik dengan hasil persentase skala sebesar $87,72 \%$. Tingkat persepsi mahasiswa Bimbingan dan Konseling semester 3 tergolong baik dengan hasil persentase skala sebesar $87,35 \%$. Tingkat persepsi mahasiswa Bimbingan dan Konseling semester 1 tergolong baik saja dengan hasil persentase skala sebesar $86,58 \%$.

2. Tingkat persepsi mahasiswa Bimbingan dan Konseling Universitas Muhammadiyah Metro secara keseluruhan terhadap profesi Guru Bimbingan dan Konseling tergolong sangat baik dengan hasil persentase rata-rata sebesar $88,39 \%$.

\section{Saran}

Berdasarkan hasil penelitian ini, maka peneliti memberikan beberapa saran antara lain sebagai berikut:
1. Bagi Program Studi Bimbingan dan Konseling Agar dapat memperbanyak pelatihan-pelatihan

Bimbingan dan Konseling pengalaman dan wawasan mahasiswa Bimbingan dan Konseling semakin bertambah.

2. Bagi Para dosen Bimbingan dan Konseling

Agar memberikan mahasiswa Bimbingan dan Konseling kesempatan untuk lebih banyak berinteraksi dengan guru Bimbingan dan Konseling secara langsung di sekolah-sekolah.

3. Bagi mahasiswa Bimbingan dan Konseling

Di masa yang akan datang mahasiswa Bimbingan dan Konseling tidak hanya cukup dengan mempersepsikan saja, namun juga harus menerapkan persepsi positifnya untuk menjalankan profesi guru Bimbingan dan Konseling dengan baik 


\section{DAFTAR PUSTAKA}

Chaplin. 2008. Kamus Lengkap Psikologi. Jakarta: PT Raja Grafindo

Harnoto dan Sudarmajdi. 2012. Psikologi Konseling Edisi Revisi. Jakarta: Prenada Media Group.

Nirwana, Herman. 1998. "Persepsi Klien Tentang Konseling, Keterampilan Komunikasi Konselor dalam Konseling dan Hubungan Keduanya dengan Pengungkapan Diri Klien". Tesis tidak diterbitkan. Malang: IKIP Malang.

Nurhadi, M.A. 2005. Sertifikasi Kompetensi Pendidik, Makalah. Fakultas Ilmu Pendidikan Universitas Negeri Padang

Peraturan Menteri Pendidikan dan Kebudayaan Repubik Indonesia No 81. A Tahun 2013 tentang Implementasi Kurikulum 2013

Peraturan Menteri Pendidikan Nasional No 27 Tahun 2008 tentang Standar Kualifikasi Akademik dan Kompetensi Konselor.

Peraturan Pemerintah Nomor 74 Tahun 2008 tentang Guru

Rakhmat, J. 2005. Psikologi Komunikasi. Bandung: Remaja Rosda Karya
Ridwan. 2005. Metode dan Teknik Menyusun Tesis. Bandung: Alfabeta

Sasanti.2008. Teori Psikologi. (http:// panji.bogspot.com). Diakses tanggal 22/11/2011

Sukmadinata, N.S. 2012. Metode Penelitian Pendidikan. Bandung: PT Remaja Rosdakarya 